\title{
Regional trends in cigarette smoking behaviour in the United States
}

Stephen E Marcus, John P Pierce, Gary A Giovino, Joel C Kleinman, Thomas E Novotny

\begin{abstract}
Objective To examine trends in cigarette smoking behaviour by region of the United States from 1965 to 1987.

Design Survey.

Setting US population.
\end{abstract}

Participants Random population based samples (9000 to 89000$)$ of adults aged $\geqslant 20$ years from 12 national health interview surveys.

Main outcome measures Cigarette smoking prevalence, initiation, and cessation.

Results Prevalence declined markedly in all four regions over time. The magnitude of the declines varied significantly among the regions; it was highest in the northeast and the west and lowest in the south. Some of these differences can be explained by differences in the magnitude of the changes in initiation and quitting among the regions. The south had the smallest decline in initiation and the smallest increase in quitting while the northeast had the greatest decline in initiation and the greatest increase in quitting. Differences in education explained only some of these regional differences. In both education groups (no college education and some college education) smoking behaviour changed the most in the northeast and the west, and changed the least in the south. However, these differences were only significant in the no college group. Moreover, smoking behaviour changed more in the higher education group than in the lower education group in all four regions.

Conclusions The public health community needs to intensify its anti-smoking efforts in the south, particularly for those who have not attended college. Monitoring geographical variations in smoking behaviour in other parts of the world would help identify high risk areas where smoking behaviour is changing slowly or not changing and would increase the effectiveness of local tobacco control programmes.

\section{Introduction}

Patterns of cigarette smoking in a society are known to be influenced by numerous environmental forces. ${ }^{1}$ Given that these forces are likely to vary among different regions of a country, one way to examine the impact of the environment on tobacco use is to study regional variations in smoking behaviour.

Recent national and state surveys have indicated that adult smoking prevalence in the United States varies markedly across states. ${ }^{2-5}$ The 1985 current population survey showed that the percentage of smokers ( $\geqslant 16$ years old) varied from $15 \%$ in Utah to $35 \%$ in Nevada. ${ }^{2}$ In 1985 smoking prevalence was highest in the south $(30 \%)$ and lowest in the west $(25 \%){ }^{2}$ Data from the 1988 behavioral risk factor surveillance system ${ }^{3}$ also showed geographical variation in smoking patterns - percentages of current adult smokers ( $\geqslant 18$ years old) ranged from $18 \%$ in Utah to $38 \%$ in Kentucky. None of these studies, however, examined trends in regional smoking behaviour.

Therefore, in this study we examined regional trends in the prevalence, initiation, and cessation of cigarette smoking in the United States between 1965 and 1987. We assessed whether the time trends in smoking behaviour in the four regions of the United States are sufficiently different so as to be a good model for studying the impact of environmental influences on smoking behaviour.

\section{Methods}

DATA SOURCES

The National Center for Health Statistics, through the national health interview survey has collected standardised information on cigarette smoking behaviour in 12 separate, random population surveys between 1965 and 1987. (Surveys were conducted in 1965, 1966, $1970,1974,1976,1977,1978,1979,1980$, 1983, 1985, and 1987.) Details of the national health interview survey methods, which have been modified once per decade, have been presented previously. ${ }^{6-9}$ During our study period two major changes occurred in sampling methodology. Firstly, before 1974 the national health interview survey asked respondents to report smoking information on all members in their households. Because information about smoking status (current, former, or never smoker) collected from proxy family members has been shown to be valid, ${ }^{1011}$ we maintained these survey years in the study. Secondly, the modifications to sampling design for the 1985-7 surveys include oversampling of black people to produce more precise estimates for this population subgroup. Since the estimates presented are weighted to reflect the popu- 
lation in the United States these modifications have been taken into account in our analyses.

\section{STUDY POPULATION}

Because the minimum age of respondents varied across survey years, we restricted the study population to adults aged 20 years and over, as in previously published papers. ${ }^{91213}$ In addition, occasional smokers - at most $3 \%$ of the total sample available from each survey were deleted from the analyses because this group was not uniformly defined. In some survey years the supplemental questionnaire on tobacco use was administered only to a subsample of the population surveyed in the national health interview survey. Therefore, sample size ranges between 9000 and 89000 across survey years.

\section{VARIABLE DEFINITIONS}

Smoking behaviour (see appendix)

An ever smoker was defined as a person who had smoked at least 100 cigarettes in his or her life. A current smoker was an ever smoker who reported smoking regularly at the time of the survey; a former smoker was an ever smoker not smoking at the time of the survey. Smoking prevalence in the 20-24 year age group is used as a proxy for smoking initiation. ${ }^{1912} \mathrm{We}$ discussed limitations of this proxy in several previous papers. ${ }^{1912}$ The quit ratio is defined as the proportion of ever smokers who are former smokers at the time of the survey. ${ }^{14}$

\section{Region}

The Bureau of the Census has divided the United States into four geographical regions: northeast, northcentral, south, and west (appendix). The national health interview survey draws representative samples from each of these regions. ${ }^{6-8}$ One previously cited report showed that states with both the highest and the lowest smoking prevalence were in the same region, ${ }^{2}$ suggesting the value of subregional analyses. However, it was not possible to further examine trends in smoking behaviour using a more detailed geographical breakdown owing to small sample sizes.

\section{Education}

In a previous paper we showed different trends in smoking behaviour across educational levels. ${ }^{12}$ Because there are also significant differences in education among the regions, we examined the role of education in explaining regional variations in smoking behaviour. We also showed that educational level could be collapsed, with only minimal loss of information, into two categories: people who attended college ( $>12$ years of education) and people who did not attend college $(\leqslant 12$ years). ${ }^{12}$ Therefore, we derived education specific estimates of smoking prevalence, initiation, and the quit ratio for each survey year.
STATISTICAL ANALYSIS

We weighted all data to reflect the United States population and to account for other design features of the particular survey. Data from all years were standardised by age to the 1985 United States population (using the five age groups: $20-29 ; 30-39 ; 40-49 ; 50-59$; $\geqslant 60$ ) to control for changes in the age structure over time. We used linear regression (SAS PROC REG) ${ }^{15}$ to model trends in the three measures of smoking behaviour over the period of the study. The year of the survey - that is, time - was the independent variable in all models. These analyses were identical to those used in previous papers. ${ }^{91213}$ In addition, we used analysis of variance (ANOVA) (SAS PROC GLM with CLASS REGION statement ${ }^{15}$ to rest for overall regional differences in trend. We entered a REGION`YEAR interaction term into these ANOVA models to test whether or not, as a group, the estimated slopes or rates of changes in smoking behaviour were significantly different from one another.

For the overall analyses separate regression models were run for each region of the country for each measure of smoking behaviour. Then we ran education specific models - that is, four separate regional models for each smoking measure and for each level of education. In addition, ANOVA models containing main effects and a REGION*YEAR interaction term were run for the overall study population and for each education subgroup of the population.

We used $r^{2}$ to measure the percentage of variation in smoking behaviour explained by each regression model. In a sense, this statistic is a measure of the strength of the linear relation between the predictor variable(s) and smoking behaviour. ${ }^{16}$

Given the large variation in sample size across surveys (from 9000 to 89000), the regression assumption of homoscedasticity does not hold. Therefore, all regressions used the method of weighted least squares to deal with variance heterogeneity; the weight is the reciprocal of the standard error for each survey. ${ }^{16}$

\section{Results}

SMOKING PREVALENCE

Trends in age adjusted smoking prevalence for the four regions from 1965 to 1987 showed a marked decline in smoking prevalence in all regions of the country (table 1). However, the magnitude of the declines varied significantly among the regions $(p<0.01)$; it was highest in the northeast and the west (the total decrease from 1965 to 1987 was approximately 15 percentage points), followed by the northcentral (11 percentage points), and lowest in the south ( 8 percentage points) (table 1$)$. As a result of its slow decline, the south moved from the lowest to the highest smoking prevalence between 1965 and 1987 .

SMOKING INITIATION

Trends in initiation showed a marked decline 


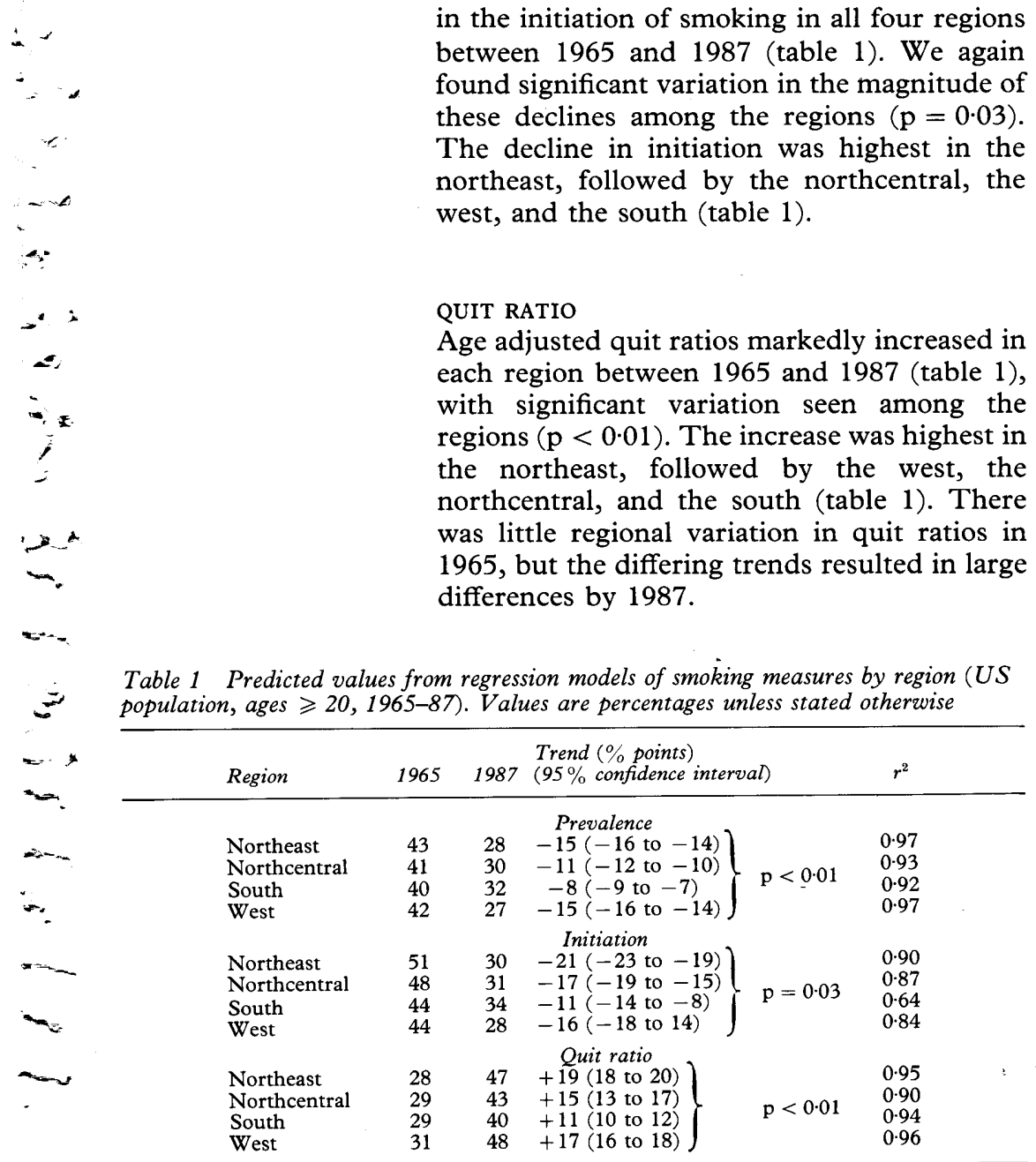

Source: National health interview surveys, 1965-87.

Table 2 Predicted values from regression models of smoking measures by education and region (US population, ages $\geqslant 20,1965-87$ ). Values are percentages unless stated otherwise

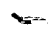

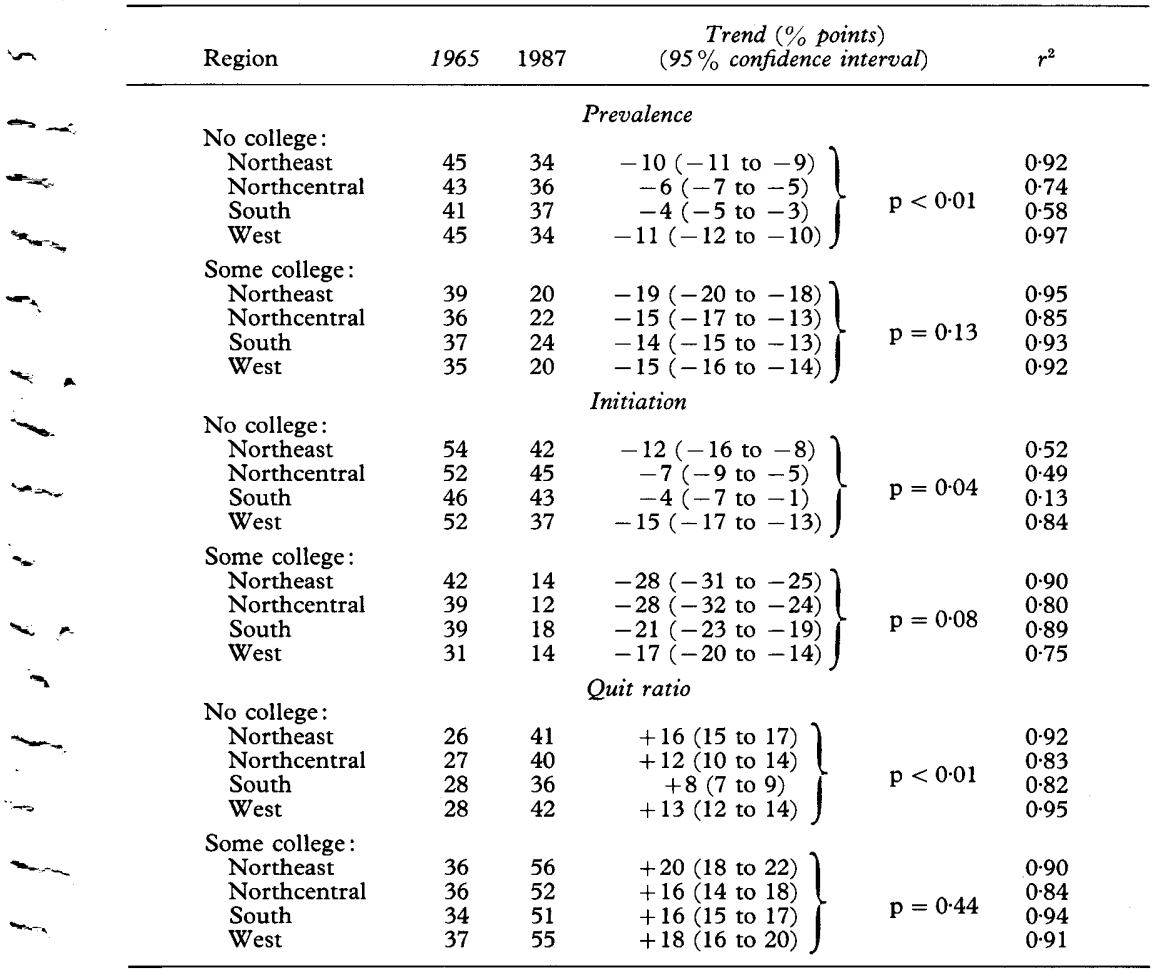

Source: National health interview surveys, $1965-87$.
DIFFERENCES BY EDUCATIONAL LEVEL

The regions differ in the educational level of their populations. For example, in 1987, the proportion who had attended at least some college was $46 \%$ in the west, $39 \%$ in the northeast, and $36 \%$ in the northcentral and in the south. Because education varies among the regions and smoking behaviour trends vary by education, ${ }^{12}$ education specific analyses were carried out. We modelled the three measures of smoking behaviour in the population within each of the two levels of education using linear regression analysis.

\section{PREVALENCE STRATIFIED BY EDUCATION}

For both education groups, we found marked declines in age adjusted smoking prevalence in all four regions from 1965 to 1987 (table 2). For those with no college education, the magnitude of these declines varied significantly among the regions $(p<0.01)$. Prevalence declined more in the west and the northeast than in the northcentral and the south (table 2). As seen before in the overall sample, the south moved from the lowest to the highest smoking prevalence between 1965 and 1987 owing to its slow decline.

For those with some college education the magnitude of the declines in prevalence among the regions was not found to be significantly different $(p=0 \cdot 13)$, due in part to the smaller number of people who had attended college. However, prevalence seemed to decline more over time in the northeast than in the other three regions (table 2).

Regardless of region, smoking prevalence declined more in people with some college education than in those with no college education. Regional declines in prevalence ranged from 4 to 11 percentage points in those with no college education and from 14 to 19 percentage points in those with some (table 2).

\section{INITIATION STRATIFIED BY EDUCATION}

We found marked regional declines from 1965 to 1987 in smoking initiation in both education groups (table 2). For those without college education these declines varied significantly among the regions $(p=0.04)-$ from a high of 15 percentage points in the west to a low of 4 percentage points in the south.

For those who had attended college regional variation in the declines in initiation was marginally significant $(\mathrm{p}=0.08)$ (table 2$)$. However, it seems that initiation declined more in the northeast and the northcentral regions than in the south and the west.

Moreover, for three of the four regions smoking initiation declined substantially more for those with some college education than for those with none (table 2). Initiation declined 17 to 28 percentage points in those with some college education compared with 4 to 15 percentage points in those with no college education. In the west, however, the magnitude of the declines in initiation was similar across educational levels, being 17 percentage points in those with some college education 
and 15 in those with none. However, the west started the period with an unusually low initiation rate among the higher education group in 1965.

\section{QUIT RATIO STRATIFIED BY EDUCATION}

Trends in age adjusted quit ratios show marked increases in all four regions for both education groups (table 2). In the lower education group the increases varied significantly in magnitude among the regions $(p<0.01)$. The quit ratio increased the most in the northeast (16 percentage points) and the least in the south ( 8 percentage points); the increase was intermediate in the west and the northcentral (13 and 12 percentage points, respectively).

In the higher education group we did not find significant regional variation in the magnitude of the increases in the quit ratio from 1965 to $1987(p=0.44)$ (table 2$)$. The increases were quite similar among the regions.

Except in the south, the quit ratio showed smaller educational differences over time than either smoking prevalence or initiation (table 2 ). In the south the magnitude of the quit ratio increase in those with some college education (16 percentage points) was twice the magnitude of this increase in those with no college education ( 8 percentage points).

\section{Discussion}

We used data from 12 national health interview surveys carried out between 1965 and 1987 to identify changes in three measures of smoking behaviour by region of the United States. These data show that significant differences in trends in prevalence, initiation, and quitting have occurred among the four major regions of the United States.

Smoking prevalence declined in all four regions from 1965 to 1987 , but the magnitude of the declines varied significantly among the regions; it was lowest in the south and highest in the northeast and west. Some of these differences can be explained by differences in the magnitude of the declines in smoking initiation and of the increases in quitting among the regions. The south had the smallest decline in initiation and the smallest increase in quitting while the northeast had the greatest decline in initiation and the greatest increase in quitting.

Many reasons may explain why the four regions of the country exhibit different patterns of smoking behaviour. One explanation may relate to differences in tobacco production among the regions. More tobacco is grown in the south than in the other regions. ${ }^{17}$ Several studies have shown a positive relation between the degree of family involvement in tobacco production and the use of tobacco products in adolescents. ${ }^{18-20}$ Other research has shown the effects of self interest on opinions about public smoking restrictions and taxation. ${ }^{2122}$ This may partially explain why disincentives to smoking, such as excise taxes on cigarettes ${ }^{23}$ and restrictions on where smoking may occur, ${ }^{1}$ are considerably weaker in the south.
Migration between the regions and immigration into the United States during the 22 year period of this study may have affected our findings. However, no data are available to address these issues, and given their complexity, we cannot give an opinion about the overall effect of either immigration or migration patterns. For example, the effects of immigration can be varied and depend on many factors, such as the smoking behaviour in the countries of origin and the degree of acculturation of the immigrants.

Current smoking behaviour may be underreported owing to growing social disapproval. This underreporting could vary among the regions and account for some of our findings. However, previous research found no apparent increase in the underreporting of cigarette smoking over time. ${ }^{24}$

Sociodemographics other than age, such as race, gender, or income, might explain some of the regional differences in smoking behaviour. However, we believe that controlling for education would also probably control for a considerable part of any race effect and much of any income effect. Moreover, in balancing the need for valid and reliable models with the added complexity of the analyses and risks of overcontrolling, we decided to adjust only for age and examine the role of education in explaining regional patterns of smoking behaviour. We examined education because previous research showed education to be the most consistent predictor of smoking behaviour in the United States. ${ }^{12}$

Education specific analyses showed that differences in the educational profiles among the regions accounted for only some of the differences in smoking patterns. In both education groups smoking behaviour changed the most in the northeast and the west and the least in the south. However, these regional differences were statistically significant only in those with no college education; they were not significant in the higher education group. Moreover, we found that smoking behaviour changed more from 1965 to 1987 in the higher education group than in the lower education group in all four regions. The one exception was similar declines in initiation among education groups in the west. These results suggest that whereas the lower education group in the south was not participating fully in the secular trends in smoking behaviour occurring in the rest of the United States, the higher education group in this region was doing so to a much greater extent.

In addition to education, other cultural or social environmental forces probably vary across the regions and affect smoking behaviour. For example, differences in smoking patterns may be partially explained by differences in social influence ${ }^{2526}$ among the regions and education groups. Communities that have higher proportions of their populations attending college will have fewer smokers and higher levels of social influences against smoking. Therefore, in the west, where almost half of the population attends college, the prevalence of smokers is the lowest and the 
social pressures against starting to smoke will be more pervasive. These pervasive social influences may be the reason for the similarity in the magnitude of the declines in initiation across education groups in the west.

A more general explanation for these differences in smoking patterns can be derived from the diffusion of innovations literature.$^{2728}$ According to the diffusion hypothesis, smoking behaviour diffuses into and out of society in a predictable pattern - the proportion of people who smoke in society increases, reaches a peak, and starts to decline. This decline will be slow at first and then enters a rapid linear phase before finally slowing to an asymptote. Thus, the decline will follow an $S$ shaped curve. Regional differences either in the points in time when the diffusion process started or in the rate of progression through the process might account for some of the differences in smoking patterns that we found in this study.

If these different regional trends in smoking behaviour continue, particularly among the lesser educated, they will lead to important differences in smoking related morbidity and mortality. ${ }^{29-33}$ To reduce these differences the public health community should intensify its anti-smoking efforts in the south, particularly for those who have not attended college. Without this increased intervention, linear projections to the year 2000 (table 3) show that the south will fall farther behind the other regions, especially among those in the lower education group. Moreover, the rates of decline in prevalence seen between 1965 and 1987 will have to increase, particularly in the south and northcentral regions, if the year 2000 health objectives on tobacco use for the United States ${ }^{34}$ are to be met. One of these objectives calls for reducing smoking prevalence among those aged 20 and older to $15 \%$ in the overall population and to $18 \%$ among those with a high school education or less.

Examining geographical variation in outcome is a traditional epidemiological approach to generating aetiological hypotheses and identifying high risk populations or areas for intervention. Our analyses have shown that there are important regional differences in smoking behaviour in the United States. In more heterogeneous societies where there are greater language, cultural, and political differences, such as across the countries of Europe, we would expect even greater geographical variation. Therefore, further such research should be encouraged in other parts of the world. This research could examine variations in smoking behaviour across different nations or continents or across different geopolitical areas within individual countries.

Table 3 Linear projections to the year 2000 of smoking prevalence $(\%)$ by region, education, and overall (US population, ages $\geqslant 20$ )

\begin{tabular}{lccc}
\hline Region & $\begin{array}{c}\text { No } \\
\text { college }\end{array}$ & $\begin{array}{c}\text { Some } \\
\text { college }\end{array}$ & Overall \\
\hline Northeast & 28 & 9 & 19 \\
Northcentral & 32 & 13 & 24 \\
South & 35 & 16 & 27 \\
West & 27 & 11 & 19
\end{tabular}

These studies could also correlate geographical variations with the extent of family or community involvement in tobacco production. The positive relation between such involvement and smoking behaviour, found in studies conducted in the United States, ${ }^{18-20}$ is worth exploring further with data from other countries.

Given the limitations of cross sectional data - in particular, temporal ambiguity - research designed to collect longitudinal data would increase the ability to make causal inferences. Ongoing surveillance systems, including repeated cross sectional surveys, are an excellent way to identify high risk areas where smoking behaviour is changing slowly or not changing and to increase the effectiveness of local tobacco control programmes. For example, variations could be examined across states or counties in the United States, since this is the level at which many of the tobacco policy changes - in clean indoor air, minors' access to tobacco, and workplace smoking policies have been taking place. ${ }^{1}$ Studies using such longitudinal data could then examine the effect of variations in anti-smoking policies or legislation on geographic patterns of smoking behaviour. ${ }^{135}$

We acknowledge the National Center for Health Statistics, Centers for Disease Control, for providing the data for these analyses. We also thank Drs Ronald M Davis, Richard Rothenberg, and Seth L Emont for their helpful review of earlier drafts of this manuscript, and Dr Kantilal M Patel for computer and statistical support. An earlier version of this paper was presented at the world conference on lung of this Boston, Massachusetts, USA, on 23 May 1990.

\section{Appendix}

SMOKING BEHAVIOUR

We derived the three measures of smoking behaviour from responses to two questions. The wording of the first was essentially the same across surveys: "Have you smoked at least one hundred cigarettes during your entire life?" (1965-70); "Have you smoked at least 100 cigarettes in your life?" (1983); and "Have you smoked at least 100 cigarettes in your entire life?" (all remaining years). The second question was "Do you smoke cigarettes now?" in all 12 surveys.

REGION

Northeast

Connecticut, Maine, Massachusetts, New Hampshire, New Jersey, New York, Pennsylvania, Rhode Island, Vermont.

Northcentral

Illinois, Indiana, Iowa, Kansas, Michigan, Minnesota, Missouri, Nebraska, North Dakota, Ohio, South Dakota, Wisconsin.

South

Alabama, Arkansas, Delaware, District of Columbia, Florida, Georgia, Kentucky, Louisiana, Maryland, Mississippi, North Carolina, Oklahoma, South Carolina, Tennessee, Texas, Virginia, West Virginia.

West

Alaska, Arizona, California, Colorado, Hawaii, Idaho, Montana, Nevada, New Mexico, Oregon, Utah, Washington, Wyoming.

1 US Department of Health and Human Services. Reducing the health consequences of smoking : 25 years of progress: a report of the Surgeon General, 1989. Atlanta, Georgia : Centers for Disease Control, Office on Smoking and Health, 1989. (DHSS Publication No (CDC) 89-8411.)

2 Marcus AC, Shopland DR, Crane LA, et al. Prevalence of cigarette smoking in the United States: estimates from the 1985 Current Population Survey. FNCI 1989;81 $410-5$. 
3 Centers for Disease Control. Cigarette smokingbehavioral risk factor surveillance system, 1988. MMWR $1989 ; 38: 845-8$.

4 US Department of Health and Human Services: Health, United States, 1988. Washington, DC: Government 1232.)

5 Centers for Disease Control. Regional variation in smoking prevalence and cessation: behavioral risk factor surveillance, 1986. MMWR 1987; 36: 751-4

6 US Department of Health Education and Welfare. Health interview survey procedures, 1957-1974. Washington, DC: Government Printing Office, 1975. (DHSS Publication No (HRA) 75-1311, series 1 , No 11.)

7 US Department of Health and Human Services. The national health interview survey design, 1973-74 and procedures 1975-83. Washington, DC: Government Printing Office, 1985. (Publication No (PHS) 85-1320, series 1 , No 18 .

8 US Department of Health and Human Services. Design and estimation for the national health interview survey 1985-94. Washington, DC: Government Printing Office, 1989. (Publication No (PHS) 89-1384, series 2, No 110).

9 Fiore MC, Novotny TE, Pierce JP, et al. Trends in cigarette smoking in the United States: the changing influence of gender and race. $F A M A 1989 ; 261: 49-55$.

10 Rogot E, Reid DD. The validity of data from next-of-kin in studies of mortality among migrants. Int $\mathcal{F}$ Epidemiol $1975 ; 4: 51-4$

11 Machlin SR, Kleinman JC, Madans JH. Validity of mortality analysis based on retrospective smoking information. Stat Med 1989; 8: 997-1009.

12 Pierce JP, Fiore MC, Novotny TE, et al. Trends in cigarette smoking in the United States: educational differences are increasing. FAMA 1989;261:56-60.

13 Pierce JP, Fiore MC, Novotny TE, et al. Trends in cigarette smoking in the United States: projections to the cigarette smoking in the United States:

14 Pierce JP, Aldrich RN, Hanratty S, et al. Uptake and quitting smoking trends in Australia. Prev Med 1987; 16 $252-60$.

15 SAS Institute Inc. SAS user's guide: statistics, version 5 edition, 655-710. Cary, North Carolina: SAS Institute, 1985

16 Kleinbaum DG, Kupper LL, Muller KE. Applied regression analysis and other multivariable methods. (2nd ed.) Boston, Massachusetts : PWS-Kent Publishing, 1988.

17 US Bureau of the Census. Statistical Abstract of the United States : 1990. 110th ed. Washington, DC: Government Printing Office, 1990.

18 Noland MP, Kryscio RJ, Riggs RS, et al. Use of snuff, chewing tobacco, and cigarettes among adolescents in a tobacco-producing area. Addict Behav 1990;15: 517-30.
19 Higgins CW, Whitley KN, Dunn JD. A comparison of smoking related attitudes and behaviors among Kentucky public school children whose families are and are not public school children whose families are and are not
involved in tobacco production. $f$ Sch Health $1984 ; 54$ : involved $185-7$.

20 Wilson RW, Higgins CW. Smoking behavior and the tobacco crop. $\mathcal{F}$ Sch Health 1984; 54: 343-6.

21 Dixon RD, Lowery RC, Levy DE, et al. Self-interest and public opinion toward smoking policies: a replication and extension. Public Opinion Quarterly 1991; 55: 241-54.

22 Green DP, Gerken AE. Self-interest and public opinion toward smoking restrictions and cigarette taxes. Public Opinion Quarterly 1989; 53:1-16.

23 Tobacco Institute. The tax burden on tobacco, 1988. Washington, DC: Tobacco Institute, 1989.

24 Hatziandreu EJ, Pierce JP, Fiore MC, et al. The reliability of self-reported cigarette consumption in the United States. Am F Public Health 1989; 79: 1020-3.

25 Farrell P, Fuchs VR. Schooling and health: the cigarette connection. F Health Economics 1982; 1: 291-8.

26 Pierce JP, Dwyer T, Chamberlain A, et al. Targeting the smoker in an antismoking campaign. Prev Med 1987;16: $816-24$

27 Rogers EM. Diffusion of innovations. 3rd ed. New York Free Press, 1983.

28 Ferrence RG. The rise and fall of cigarette smoking in North America. New York: Garland Publishing, 1990.

29 Centers for Disease Control. Chronic disease reports chronic obstructive pulmonary disease mortality United States, 1986. MMWR 1989; 38: 549-52.

30 Centers for Disease Control. State-specific smokingattributable chronic obstructive pulmonary disease mortality - United States, 1986. MMWR 1989; 38: 552-4, 559-61.

31 Centers for Disease Control. Chronic disease reports: stroke. $M M W R$ 1989; 38: 191-3.

32 Centers for Disease Control. Chronic disease reports: coronary heart disease mortality - United States, 1986 coronary heart disease mo
$M M W R$
$1989 ; 38: 285-8$.

33 Centers for Disease Control. Chronic disease reports: deaths from lung cancer-United States, 1986. $M M W R$ $1989 ; 38: 501-5$.

34 Public Health Service. Healthy people 2000 : national health promotion and disease prevention objectives. Washington DC: Government Printing Office, 1991. (Publication No (PHS) 91-50212.)

35 Rigotti NA, Pashos CL. No-smoking laws in the United States: an analysis of state and city actions to limit smoking in public places and workplaces. $7 A M A 1991$ 266: 3162-7.

a la baisse la plus faible pour l'initiation et l'augmentation la plus faible pour la cessation alors que le nord-est a la plus grande baisse pour l'initiation et la plus grande augmentation pour la cessation. Les différences d'éducation n'expliquent que partiellement ces différences régionales. Dans les deux groupes d'éducation (pas de formation universitaire ou une certaine formation universitaire) le comportement a le plus changé dans le nord-est et l'ouest, et il a le moins changé dans le sud. Ces différences n'étaient cependant significatives que dans le groupe de personnes n'ayant pas de formation universitaire. De plus, dans les quatres régions, le comportement tabagique a plus changé dans le groupe de personnes ayant un niveau d'études plus élevé que dans le groupe de personnes ayant un niveau d'études inférieur.

Conclusions: Les organisations de santé public doit intensifier leurs efforts anti-tabac dans le sud, en particulier auprès de ceux qui n'ont pas de formation universitaire. Suivre les variations géographiques des comportements tabagiques dans d'autres parties du monde aiderait à identifier les zones à haut risque, dans lesquelles le comportement tabagique évolue lentement ou n'évolue pas du tout, et d'améliorer l'efficacité des programmes locaux de prévention du tabagisme. 


\section{Tendencias regionales en el comportamiento de fumar cigarrillos en los Estados Unidos}

Stephen E Marcus et al

\section{Resumen}

Objetivo: Examiner las tendencias en el comportamiento de fumar cigarrillos en las distintas regiones de los Estados Unidos desde 1965 a 1987.

Diseño: Encuesta.

Marco: La población de EUA.

Participantes: Muestras aleatorias de la población (9000 a 89.000) de adultos de 20 años tomadas de 12 encuestas nacionales basadas en entrevistas sobre el estado de salud.

Principales evaluaciones obtenidas: Prevalencia del tabaquismo y de iniciación y cese de ese hábito.

Resultados: Con el transcurso del tiempo la prevalencia cayó notablemente en las cuatro regiones.

La magnitud de la caída varió significativamente según las regiones; fue más pronunciada en el nordeste y el oeste y mínima en el sur. Estas variaciones se explican en parte por las diferencias entre las regiones en lo que respecta a la magnitud de los cambios en la iniciación y el cese del tabaquismo. La caída más pequeña en la iniciación y el aumento más pequeño en el cese ocurrieron en el sur, mientras en el nordeste se observaron la mayor caída en la iniciación y el aumento mayor en el cese del tabaquismo.

Las diferencias en el nivel de educación explican solo en parte estas diferencias regionales. En los dos grupos según el nivel de educación (sin educación universitaria o con alguna educación universitaria) la modificación máxima del comportamiento se produjo en el nordeste y el oeste y la minima, en el sur. Sin embargo estas diferencias fueron significativas solo en el grupo sin educación universitaria.

Además, en las cuatro regiones el comportamiento en materia de tabaquismo cambió más en el grupo con el mayor grado de educación que en el grupo con menos educación.

Conclusiones: La comunidad de salud pública tiene que intensificar sus esfuerzos contra el tabaquismo en el sur, en particular entre los que no han recebido educación universitaria.

La observación de las variaciones geográficas en el comportamiento del tabaquismo en otras partes del mundo ayudaría a identificar las áreas de alto riesgo donde dicho comportamiento está cambiando lentamente, o no se modifica, y a aumentar la efectividad de los programas locales de lucha contra el tabaco.

\section{美国吸烟行为的地区性趋势 斯帝芬.马库斯等}

\section{目标：调查从1965 年一 1987 年美国吸烟行为的地区性趋势 \\ 设计: 随机抽样调查}

调查对象: 从 12 项全国健康采访调查中，随机抽出9000到 89,000 二十周岁成年人

调查主要内容: 卷烟吸烟率、新增加吸烟者情况、戒烟情况

结果: 四个地区的吸烟率下降显著, 地区间下降幅度有明显差异, 北部和西部下降幅度最 大, 南部最少。这些区别中有些是由于各地区新增加吸烟者数量以及戒烟者数量的不同而造 成的。美国南部地区新增加吸烟者最多而戒烟者又最少。东北地区新增加吸烟者最少, 并且 戒烟者最多, 受教育水平也是地区间差别原因之一, 但影响不大, 两组（受国高等教育的人 和未受过高等教育的人) 中行为改变率在北部和西部最高, 而南部地区最低。但是这类差别 只在未受过高等教育的人中间比较显著。总而言之, 受教育水较高的人群中的吸烟行为改变 大于受教育水平较低的人群吸烟行为变化。

结论: 公共卫生界需要加强在美国南部的反吸烟教育, 特别是要加强对未受过高等教育的人 群的教育。对世界其他地区吸烟行为的变化进行监测将有助于发现吸烟率下降缓慢或没有变 化的高危地区，进而提高本地烟草控制项目的效果。

(中国健康教育研究所烟草控制与疾病预防研究室 郑保义译)

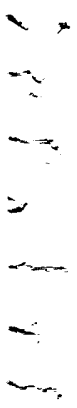

